\title{
The Relation between Thermal Performance and Architecture Design Aspects in Lowland Warm Humid Tropics Ward
}

\author{
Yuyus Mulia $^{\# 1}$, Gagoek Hardiman ${ }^{* 2}$, Kamal A. Arif ${ }^{\# 3}$ \\ ${ }^{\# 1}$ Doctoral Candidate in Architecture of Parahyangan Catholic University, Bandung 40117, Indonesia \\ E-mail: yuyusmulia@yahoo.com \\ *2Department of Architecture, Diponegoro University, Semarang 50275, Indonesia \\ E-mail: ggkhar@yahoo.de \\ ${ }^{\# 3}$ Department of Architecture, Parahyangan Catholic University, Bandung 40117, Indonesia \\ E-mail: kamal.a.arif.73@gmail.com
}

\begin{abstract}
According to the sustainable architecture theories, the building with a high level of thermal performance is the building that has the high percentage of thermal comfort accomplishment and low level of energy consumption. Thermal comfort is a building's criteria in order to make the building's users activity become optimal. It can be achieved by natural ventilation/NV system and air conditioning/AC system that may either preserve or consume a great deal of fossil energy. Hence, climatic parameters and architecture design aspects could always determine its accomplishment. Ward is the primary section of hospital installation which functions as patient's house while they undergo their healing process, whereas hospital is a primary public facility in any contemporary urban setting. From the energy using side, hospital is the public building type that has high level of fossil energy consumption. Therefore, the development of high level's thermal performance ward will contribute to environment sustainability by reducing its fossil energy combustion. For that matter, it is then important to know which ward's design aspects that may become the dominant factors for the thermal comfort establishment and efficient energy use. The goal of this research is mainly to disclose the relationship between thermal performance and architecture design aspects in lowland warm humid tropics ward. The research methods are quantitative method (by using statistical test, linear regression analyses and correlative analysis based on the building's physics theory) and field case study. The results of this research are the architecture design aspects of lowland warm humid tropics ward that have been dominant factors on its thermal performance level; that are the building's orientation toward the sun and the building's layout plan within the site.
\end{abstract}

Keywords - Thermal performance, Architecture design aspects, Lowland warm humid tropics, Ward

\section{INTRODUCTION}

The most thermal comfort research has been done in public building such as offices, classroom or lecture room that regularly operate about eight hours per day [1]-[10]. Yet rarely conducted in public building such as hospital ward that operates 24 hours per day along the year and even more rarely were done in the hospital wards that are located in warm humid tropics region like Indonesia [11].

Thermal comfort is one of the building's criteria in order to make the building's users activity become optimal [12]. Thermal comfort inside a building could be accomplished by natural ventilation/NV system and air conditioning/AC system that may either preserve or consume a great deal of fossil energy. Hence, climatic parameters (air temperature, radiant temperature, relative humidity, air movement) and architecture design aspects (the building's orientation toward the sun and open space around it, the building's layout plan and its rooms dimension, the building's facade) could always determine its accomplishment. According to the sustainable architecture theories, the building with good thermal performance is the building that has the high level of thermal comfort accomplishment percentage and all at once has the low level of energy consumption [13]-[17].

Hospital is a primary public facility in contemporary urban setting, and ward is the primary section of hospital installation which functions as patient's house while they undergo their healing process. From the sustainability aspect, especially on the energy using side, a hospital is the public building type that has the high level of fossil energy consumption [18]-[20]. Therefore, the development of a high level's thermal performance ward would contribute to the environment sustainability by reducing its fossil energy combustion. For that matter, it is then important to know which ward's design aspects that may become the dominant factors for the thermal comfort establishment and efficient in energy using. 
The goals of this research are mainly to disclose the relationship between thermal performance and architecture design aspects in lowland warm humid tropics ward. The thermal performance as mentioned in this study is related with the building's thermal comfort level and the building's energy consumption level, meanwhile the architecture design aspects as mentioned here are the building orientation toward the sun and open space around its, the building's layout plan and its rooms dimension, and the building's facade.

\section{MATERIALS AND METHODS}

\section{A. Methods of Study.}

The methods that conducted in this research are quantitative method (by using statistical test, linear regression analysis and correlative analysis based on thebuilding's physics theory) and field case study (in five sampling hospital wards that location in lowland area/Cirebon region. Number of respondent who participated in this research was 500 persons or 100 persons each ward. All respondent were ward's users consisted of doctors, medical and non-medical staffs, cleaning services employees, patient's visitors and families. Ward's types that become the object study are Corridor type and Courtyard type, two types of ward that during the last two decades mainly developed in Indonesia's urban area.

\section{B. Ward's Thermal Performance and its Architecture Design Aspects Conditions.}

To reveal the ward's thermal comfort level (comfort temperature and thermal comfort zone of ward's user) interview could be given to ward's user respondents as to measure the climatic parameters that occurred inside wards object study. All respondents are interviewed one by one to achieve thermal sensation votes/TSV of ward's user. Each respondent is asked to choose one of seven TSV list in ASHRAE version about room's temperature condition, which are: Very Cold (-3), Cold (-2), Cool (-1), Comfort or Neutral (0), Warm (+1), Hot (+2), Very Hot (+3) [21].

To get respondent's spontaneity and independence, when doing the TSV survey, the first question from researcher to respondent was: "What do you feel about this hospital room temperature?" Right after the answer recorded, the interview was progressed to some other questions about respondent's profile data, which includes: gender, age, body's height and body's weights. At the same time with TSV's data collection, the live conditions of four kind climatic parameter were being measured and recorded. Three among others, including: air temperature $(\mathrm{Ta})$, radiation temperature $(\mathrm{Tn})$ and relative humidity $(\mathrm{rH})$ are measured and recorded by a digital instrument, that is: HeatIndex WBGT Meter-Model: WBGT-2010SD ex Lutron.In the other hand, air flow or air movement (Am), was also being measured by Anemometer-Model:AM-4222 ex Lutron.

Field survey activities of this study (collecting TSV's data and climatic parameter data) were conducted along nine months, from March until November 2016, through the hot and rainy season, and had been done on work day hours around 08:00 am - 16:00 pm.

Tabulation and analysis process of TSV's data and climatic parameters data were conducted by statistical test and linier regression analyses to achieve the ward's user thermal comfort level [22], [23].

To find the electricity energy consumption level of hospital ward in Indonesia, a data recording could be taken from the kWh meter position during its one-month period. Since the occupancy's level of ward in Indonesia hospitals are generally constant from January until December each year. Hence, the annual electrical energy consumption use could be found by multiplying its monthly data 12 times. Furthermore, after the annual data were divided by floor area will be achieved the ward's electricity energy consumption level with unit index $\mathrm{kWh} / \mathrm{m} 2 / \mathrm{yr}$.

In this research, the activity to collect ward's electricity energy consumption data was conducted from March until November 2016. In the other hand, the field surveys to achieve the architecture design aspects condition of wards object study (which consists of: the building's orientation toward the sun and open space, the building's layout plan and its rooms dimension, the building's facade) were conducted before, during and after the TSV and climatic parameter's survey.

\section{Methods on Revealing the Relationship between Wards' Thermal Performance and its Architecture Design Aspects through Architectural Design Analyses.}

The relationship between thermal performance and architecture design aspects of wards object study could be achieved by comparing the thermal comfort accomplishment percentage and the electrical energy consumption level with the existing conditions of its architecture design aspects.

Thermal comfort accomplishment and energy consumption level of a building are influenced by climatic parameter as the external factor, and architecture design aspects as the internal factor [24]-[26]. The climatic parameter could not be somehow planned while architecture design aspects could be designed to control climatic parameters inside the building. Therefore, by architectural design analysis toward the existing building condition and based on the building's physics theory, the architecture design aspects that become the dominant factor of the building's thermal performance could be known. 
In warm humid tropics region with hot ambient temperature, the thermal comfort inside the building could be achieved by cooling the hotter outdoor air temperature. This condition will situate the indoor air temperature into a comfort temperature and hence achieves a thermal comfort zone of building's user. If the given process used mechanical/AC system, of course it would consume a lot of fossil energy. In this case, there will be occurred the building's physics law that states: the bigger the number of air temperature that would be lowered down, the bigger the building's energy that would be consumed. The previous research about building's energy shows that each reduction of $1^{\circ} \mathrm{C}$ room's temperature would consequently consume $10 \%$ of total building's energy for air conditioning system [27], [28].

Therefore, optimizing the NV system and efficiently reducing the AC system could conduct a thermal comfort accomplishment of ward in warm humid tropics region in a rather sustainable manner. However, for that purpose it is then important to identify the thermal comfort level and its relatable architecture design aspects.

According to the NV system principles in warm humid tropics region, the comfort temperature inside the building could be achieved by minimizing the solar heat gain and by maximizing the releasing process of the building's heat. That principle related with the architecture design aspects conditions such as building's orientation, the open space around the building, building's plan layout, ceiling height, form and material of building's facade, etc. In this study, there are only four main aspects that would be researched further, which include building's orientation toward the sun, open spaces around the building, building's plan layout and building's facade.

In warm humid tropics region, buildings with its length side's facing toward east-west direction would gain more heat from solar radiant, and this condition would increase the air temperature inside the building. Furthermore, building's temperature could be lowered by planting leafy trees at both sides of its volume and providing sun's shading on the building's facade. While the open space around a building covered by hard material like asphalt, concrete, stone and such, it would consequentially cause the temperature higher within the outdoor as well as the interior located adjacent to the given open space.

Building's plan layout, in other hand could also control the air movement from indoor to outdoor area, and in turn decreases the air temperature inside the building. Courtyard type with multi storeys floor, one of a ward's plan layout types that has central void from its ground floor until the roof level, could also perform the same mechanization in this matter.

The opening planes at building's facade such as doors, operable windows and ventilation holes are also among several design aspects that could provide the cross ventilation by letting air circulation to happen and lowering down air temperature inside the building [27], [28].

Research methods diagram of this study could be seen at Fig. 1 below:

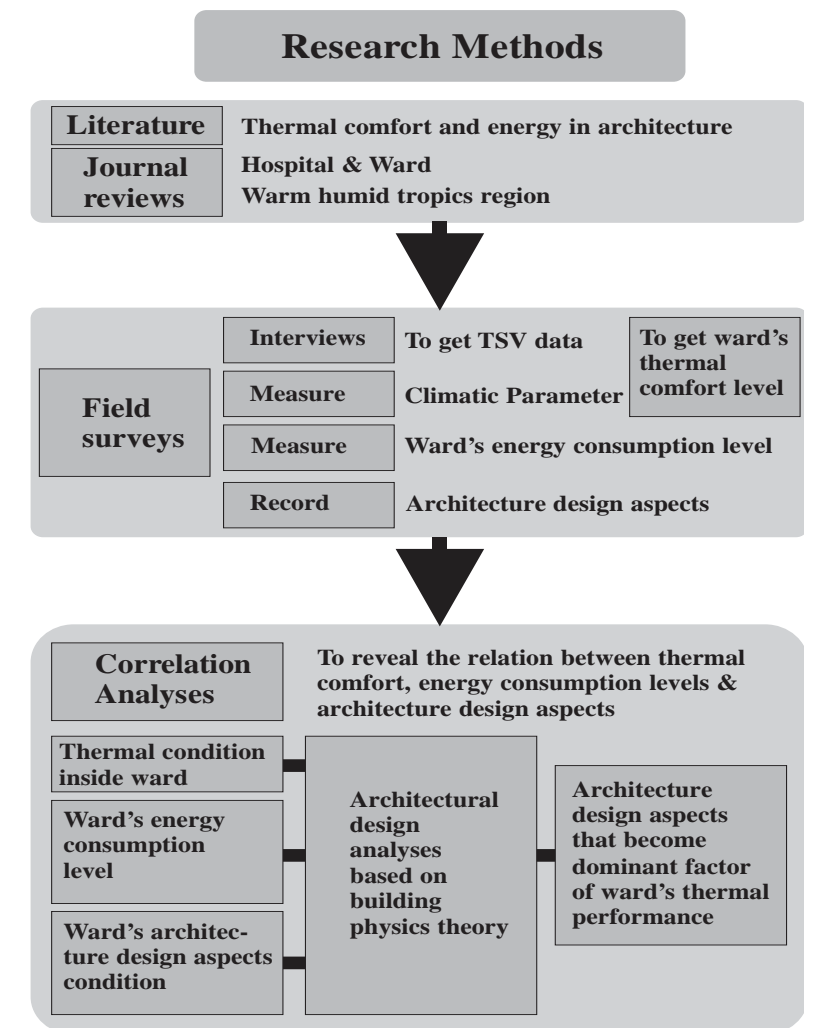

Fig.1. Research Method Diagram 


\section{The Sampling Wards of Case Study}

The sampling of the case study are five wards that located in lowland area of warm humid tropics/Cirebon region (spread on area $0-130 \mathrm{~m}$ above sea level, with ambient temperature around $22-34^{\circ} \mathrm{C}$ and relative humidity around 48-93\%), Indonesia.

The following at Tab.1 are data of wards object study with its architecture design aspects conditions:

TABLE I The Existing Conditions of Wards Object Study

\begin{tabular}{|c|c|c|c|c|}
\hline Ward Object Study & Plan Layout Type & $\begin{array}{c}\text { Open Space } \\
\text { between Building }\end{array}$ & Facade & $\begin{array}{c}\text { Air } \\
\text { System }\end{array}$ \\
\hline 1.Cideres Hospital Ward & Corridor 3 storeys & $6 \mathrm{~m}$ Hardspace & Operable Windows & $\mathrm{NV}$ \\
\hline 2.Majalengka Hospital Ward & Corridor 1 storey & $6 \mathrm{~m}$ Grass & Operable Windows & $\mathrm{NV}$ \\
\hline 3.Arjawinngun Hospital Ward & Corridor 2 storeys & $9 \mathrm{~m}$ Grass & Operable Windows & $\mathrm{NV}$ \\
\hline 4.Waled Hospital Ward & Courtyard 1 storey & $6 \mathrm{~m}$ Grass & Operable Windows & $\mathrm{NV}$ \\
\hline 5.Gunungjati Hospital Ward & Corridor 5 storeys & $6 \mathrm{~m}$ Grass & Operable Windows & $\mathrm{NV}$ \\
\hline
\end{tabular}

\section{RESULTS AND DISCUSSION}

\section{A. Comfort Temperature, Thermal Comfort Zone and Electricity's Energy Consumption Level of Wards Object} Study

The interview taken with the respondents are sampled to analyze the climatic parameter conditions and the electricity's energy consumption of case studies wards. The results are the following:

Climatic parameter conditions in five wards object study are:

Air temperature: around $24.6-32.6^{\circ} \mathrm{C}$, average $30.4^{\circ} \mathrm{C}$ Relative humidity: around $42.5-72.3 \%$, average 59.7\% Air movement:

Fig. 2 below shows the distribution of thermal sensation votes/TSV in five wards object study. From 500 respondents that participated in this study, the distribution of its TSV were that choose Cold (37 person), Cool (49), Comfort (199), Warm (40), Hot (168), Very Hot (7).



Fig.2. The Distribution of TSV in Wards Object Study in Lowland Area Hospital

Based on the climatic parameter conditions and the TSV's distribution data, regression analysis was conducted which resulted in a graphic of comfort equation as seen at Fig.3 below: 


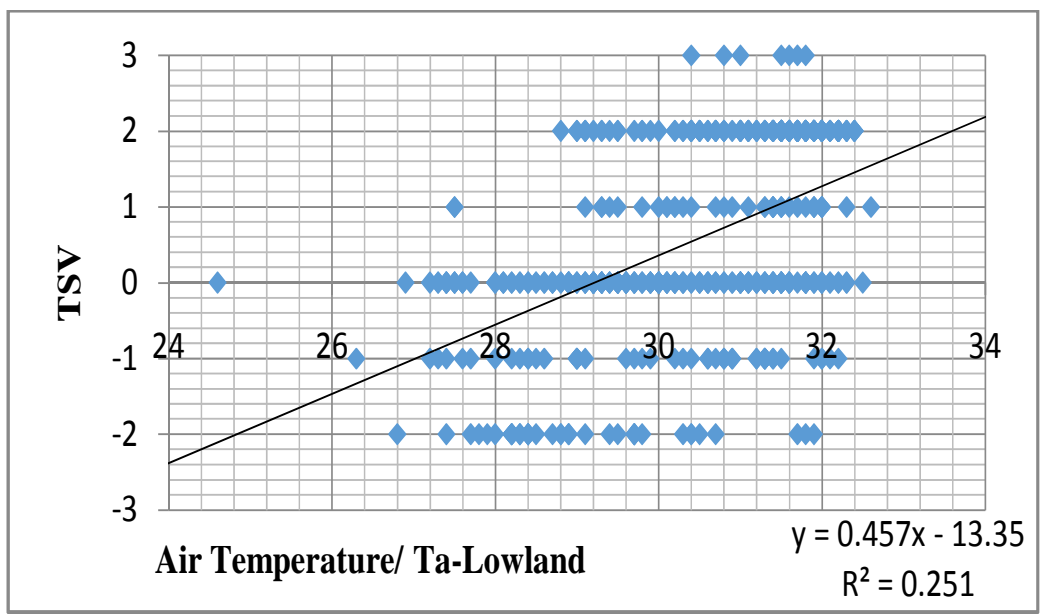

Fig.3. Regression Line of TSV in Wards Object Study in Lowland Area Hospital

Fig.3 above shows area of comfort temperature and comfort zone of respondents in the lowland area hospitals. Comfort temperature obtained based on the $95 \%$ respondents satisfied to their thermal ambient, while thermal comfort zone obtained based on the $90 \%$ respondents satisfied to their thermal ambient.

In this study, the thermal comfort equation achieved is: TSV $=0.457 \mathrm{Ta}-13.35$ with determination coefficient R2 $=0.251$. Therefore, if TSV $=0$, its comfort temperature level is $29.2^{\circ} \mathrm{C} \mathrm{TE}$. Then if TSV $=-1$ up to 1 , hence its thermal comfort zone is $28.1-30.3^{\circ} \mathrm{C}$ TE.

The thermal comfort accomplishment percentage and electricity's energy consumption level of case studies ward in the lowland area can be seen at Figure 4 below:

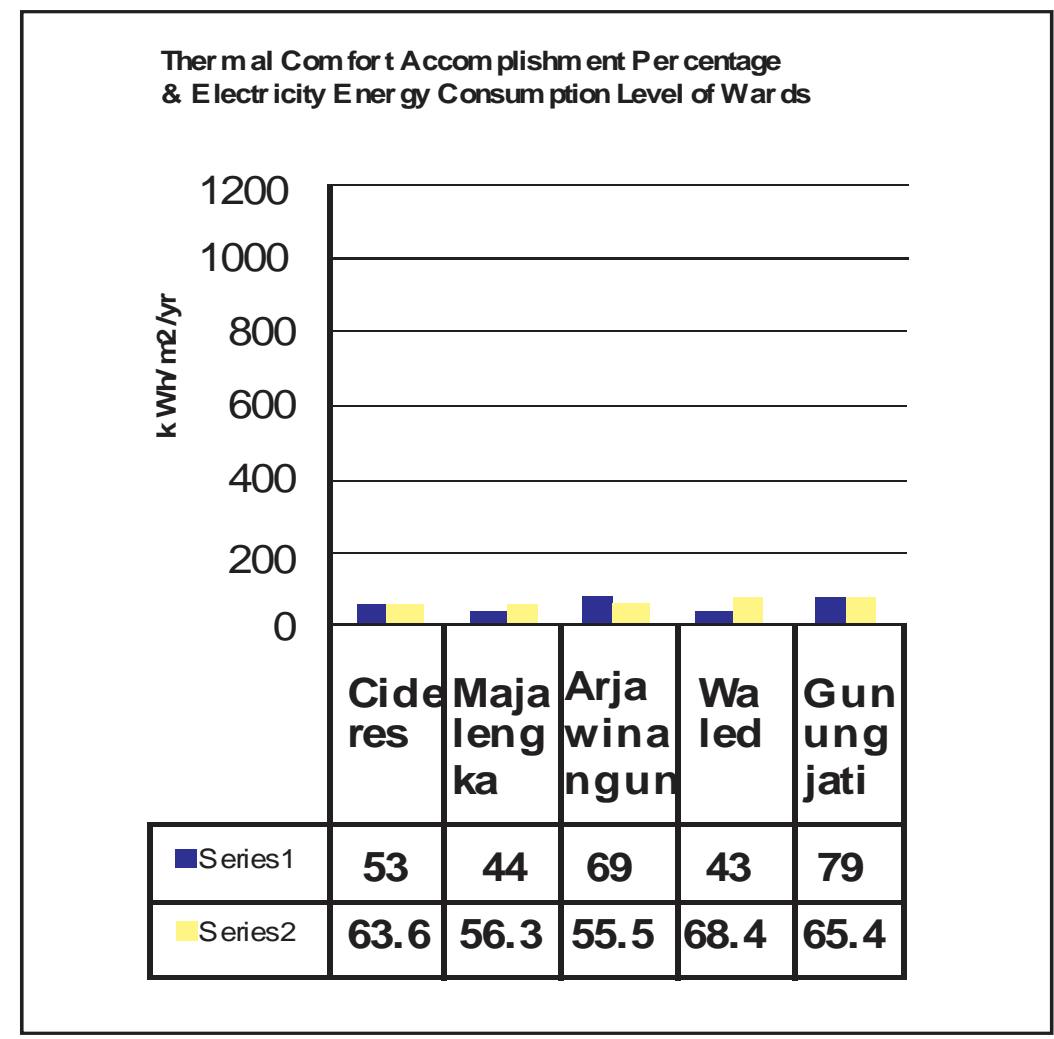

Fig.4. Thermal Comfort Accomplishment Percentage and Electricity Energy Consumption Level of Wards Object Study in Lowland Area Hospital

Table 2 below shows the electricity energy consumption level in all case studies wards in lowland area where the air system that have been dominantly used NV system. 
TABLE II The Electricity Consumption Level/ EECL of Wards Object Study in Lowland Area Hospital

\begin{tabular}{|l|c|c|}
\hline Ward Object Study & Air System & EECL (kWh/m2/yr) \\
\hline 1. Cideres Hospital Ward & NV & 63.6 \\
\hline 2. Majalengka Hospital Ward & NV & 56.3 \\
\hline 3. Arjawinangun Hospital Ward & NV & 55.5 \\
\hline 4. Waled Hospital Ward & NV & 68.4 \\
\hline 5. Gunungjati Hospital Ward & NV & 65.4 \\
\hline
\end{tabular}

According to Tab.2 above, the electricity's energy consumption level of case studies ward that dominantly used NV system are: average $61.84 \mathrm{kWh} / \mathrm{m} 2 / \mathrm{yr}$.; the highest $68.4 \mathrm{kWh} / \mathrm{m} 2 / \mathrm{yr}$. (occurred in Dahlia Ward of Waled Hospital); the lowest $55.5 \mathrm{kWh} / \mathrm{m} 2 / \mathrm{yr}$. (occurred in Imam Bonjol Ward of Arjawinangun Hospital).

Based on the results as seen at Fig.4 and Tab.2 it could be concluded that wards in lowland area with NV system that has lowest thermal performance is Dahlia Ward in Waled Hospital because its thermal comfort accomplishment percentage is $43 \%$ (the lowest among others), and its electricity's energy consumption level is $68.4 \mathrm{kWh} / \mathrm{m} 2 /$ year (the highest level among wards object study with NV system). Meanwhile ward that has the highest thermal performance is Imam Bonjol Ward in Arjawinangun Hospital with thermal comfort accomplishment percentage in $69 \%$ and its electrical energy consumption level in $55.5 \mathrm{kWh} / \mathrm{m} 2 /$ year (the lowest level among case studies wards with $\mathrm{NV}$ system).

As comparison, the following are results about comfort temperature and thermal comfort study of hospital's building user in Malaysia which geographically located in the same warm humid tropics region with its average ambient temperature around $23-32{ }^{\circ} \mathrm{C}$. The study has been done by Yau, Y.H. and B.T. Chew in 2009 involving hospital workers in Malaysia [29], where it concludes that its comfort temperature of building's user is $26.4^{\circ} \mathrm{C}$ TE (higher $0.9^{\circ} \mathrm{C}$ than Indonesia National Standard/SNI $6390: 2011,25.5^{\circ} \mathrm{C}$ TE, $2.8^{\circ} \mathrm{C}$ lower than the comfort temperature level of the lowland area researched in this study $\left(29.2^{\circ} \mathrm{C} \mathrm{TE}\right)$, as well as $1^{\circ} \mathrm{C}$ lower than the comfort temperature level of the highland area researched in this study $\left(27.4^{\circ} \mathrm{C} \mathrm{TE}\right)$. Furthermore, it also has its comfort zone in around $25.3-28.2^{\circ} \mathrm{C}$ TE. It is in fact still under the thermal comfort zone of either the lowland area $\left(28.1-30.3^{\circ} \mathrm{C} \mathrm{TE}\right)$ or the highland area $\left(26.3-28.6^{\circ} \mathrm{C} \mathrm{TE}\right)$ researched in this study respectively.

Accordingly, in 2012; Azizpour, F., S. Moghimi, C.H. Lim, S. Mat, E. Salleh and K. Sopian did the study in some of the hospital's installation and office room in Malaysia [30], which resulted in the comfort temperature of medical and non-medical staff of $26,8^{\circ} \mathrm{C}$ TE. It is $1.3^{\circ} \mathrm{C}$ higher than Indonesia National Standard/SNI 6390:2011 $\left(25.5^{\circ} \mathrm{C}\right)$ and is still lower than both of the comfort temperature resulted in the lowland area $\left(29.2^{\circ} \mathrm{C}\right.$ TE).

Thus, ward's comfort temperature and thermal comfort zone result of this study is in fact higher than the result of the hospital building studied in Malaysia.

\section{B. The Relation between Building's Thermal Performance and Architecture Design Aspects in Wards Object Study}

The following are the architecture design aspects condition of Dahlia Ward in Waled Hospital that dominantly used NV system. In this study, Dahlia Ward is one of the case studies ward located in lowland area that has had the lowest level of thermal performance. 

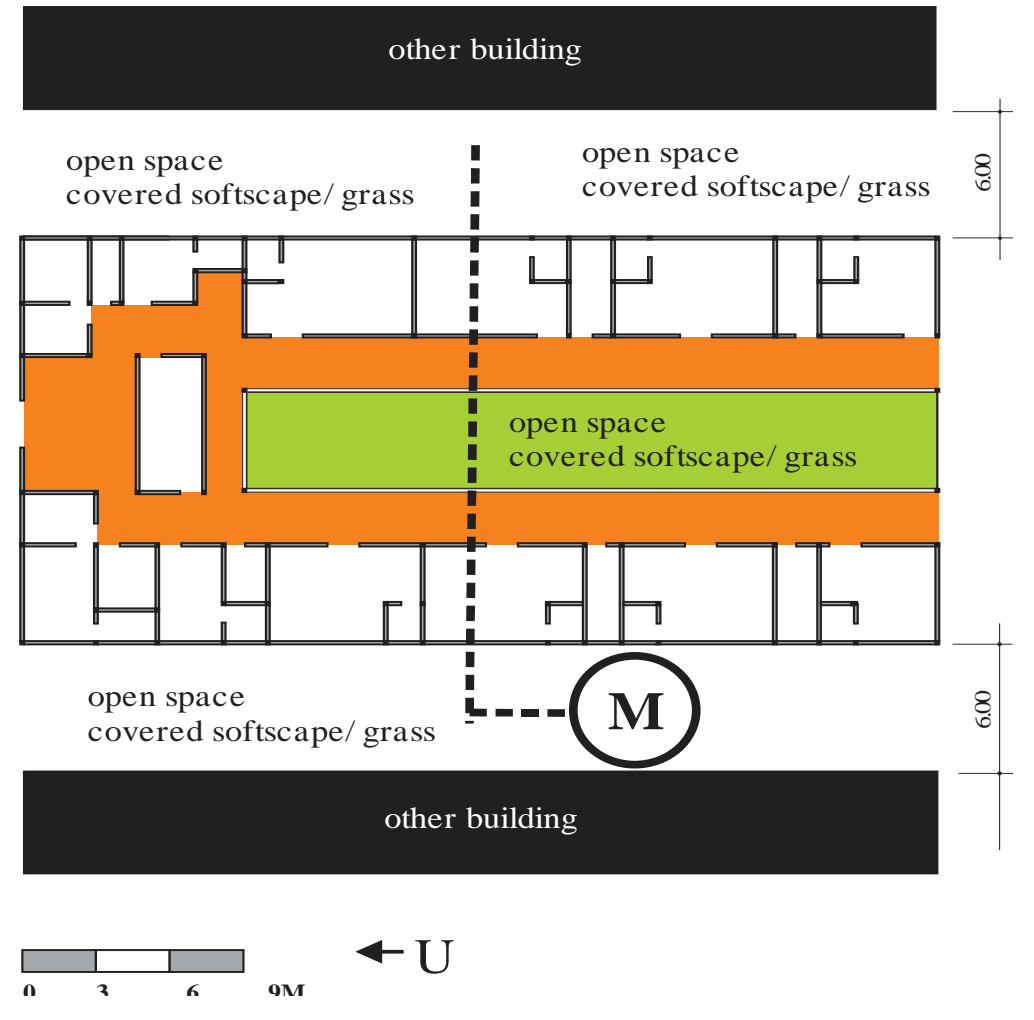

Fig.5. Layout Plan of Dahlia Ward in Waled Hospital
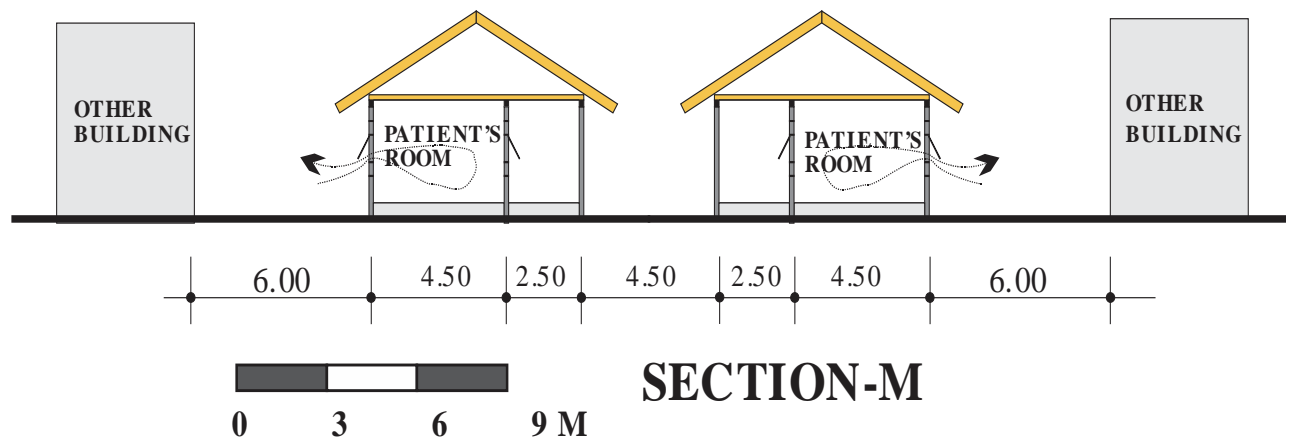

Fig. 6. Section-M of Dahlia Ward in Waled Hospital

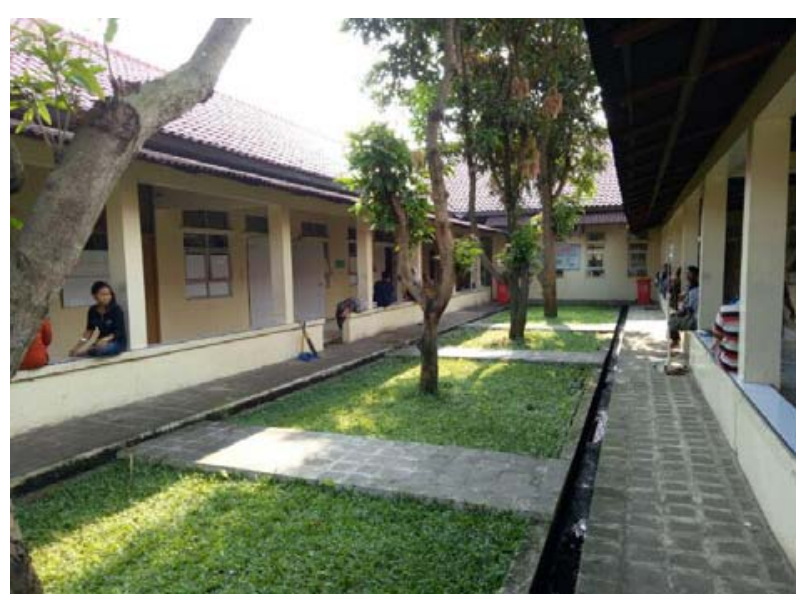

Fig.7. Courtyard of Dahlia Ward in Waled Hospital

The lower thermal performance of Dahlia Ward in Waled Hospital mainly caused by its building's orientation which faces toward east west and situates its two long facade to gain more of the solar radiation (See Fig.5,6,7). 
The following are the architecture design aspects condition of Imam Bonjol Ward in Arjawinangun Hospital that dominantly used NV system. In this study, Imam Bonjol Ward is one of the case studies ward located in the lowland area that has had the highest level of thermal performance.

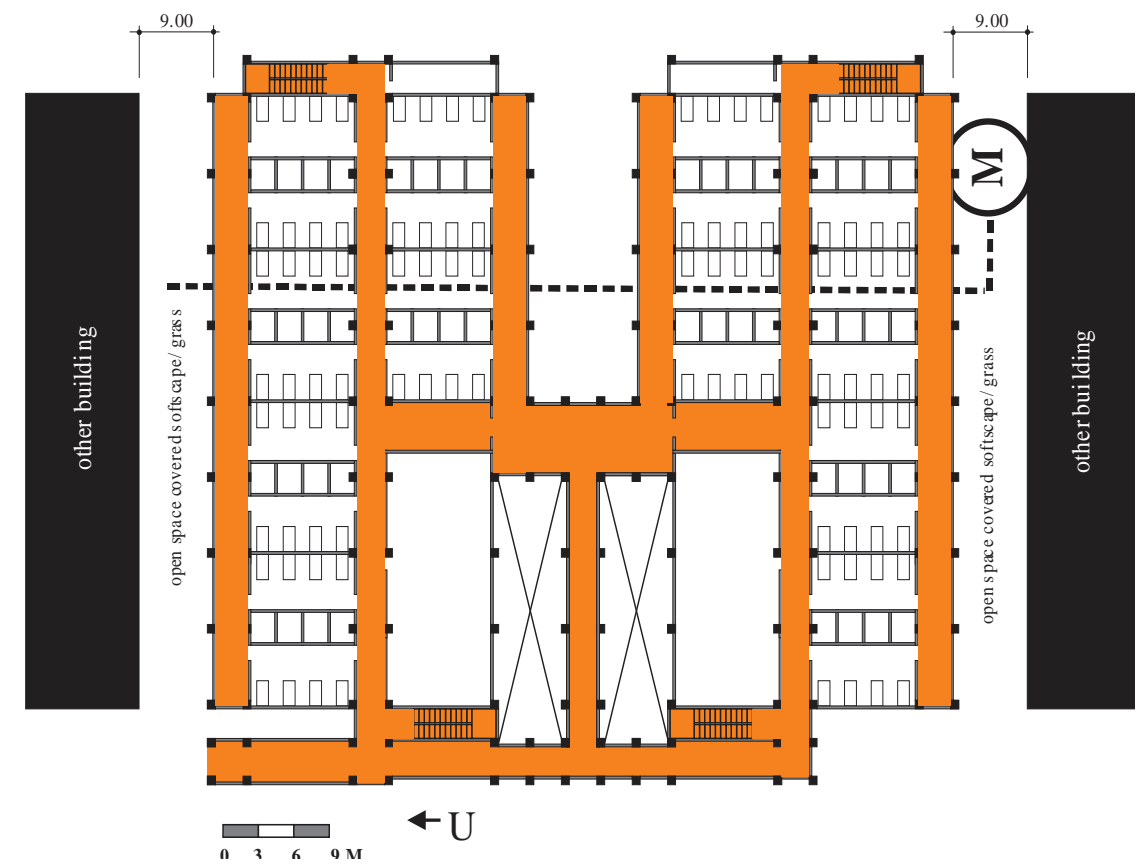

Fig.8. Layout Plan of Imam Bonjol Ward in Arjawinangun Hospital
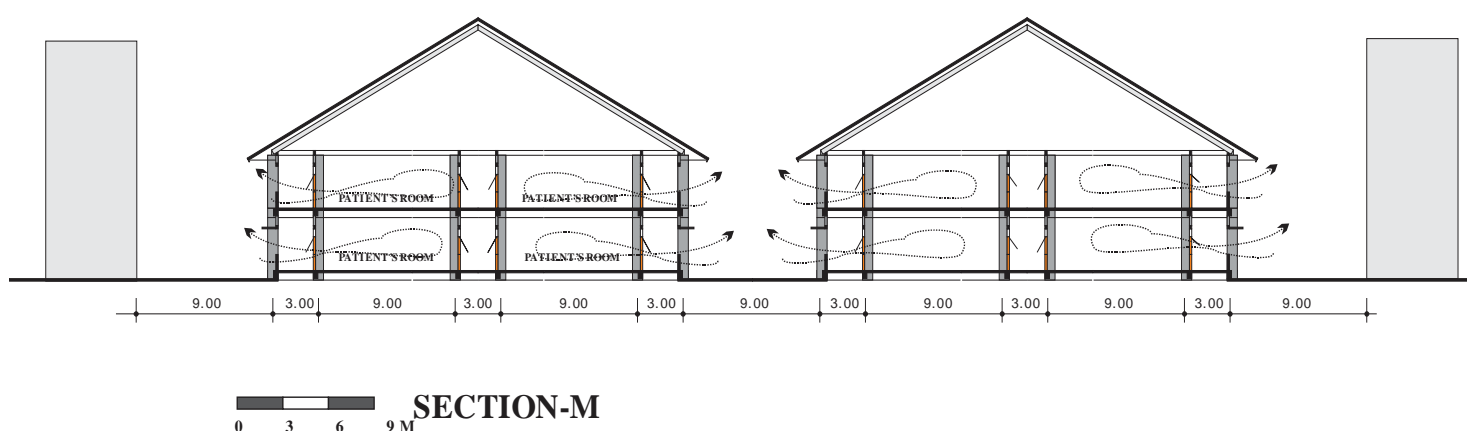

Fig.9. Section-M of Imam Bonjol Ward in Arjawinangun Hospital

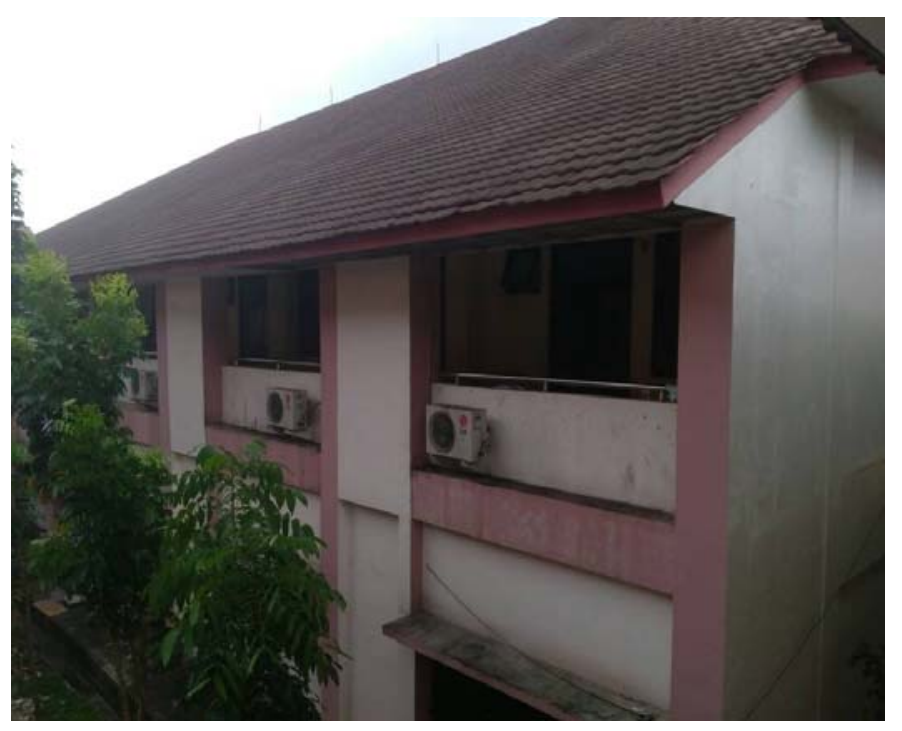

Fig.10. North Facade of Imam Bonjol Ward in Arjawinangun Hospital 
The higher thermal performance of Imam Bonjol Ward in Arjawinangun Hospital is mainly caused by its building orientation which faces toward north-south direction and its outer corridor that were able to minimize heat gains from solar radiation. Furthermore, there are also wide-open spaces around the length of the building's mass, which covered by soft material/grass, and physically made the air temperature in its surrounding area cooler. The building's architecture design aspects also has open plan with three corridors and several operable windows along two sides of its facades, making cross ventilation possible and air temperature inside the ward lower (See Fig. 8,9,10). Therefore, those architecture design aspects conditions have made thermal comfort accomplishment percentage of that ward become high, and its electrical energy consumption level become low.

\section{CONCLUSION}

The research about the relationship between thermal performance and architecture design aspects that has been done in the lowland warm humid tropics ward could be concluded with the following points:

1. The hospital wards in lowland area (that dominantly used the NV system, with ambient temperature around $22-34^{\circ} \mathrm{C}$ and air relative humidity around $48-93 \%$ ) have the comfort temperature of ward's user in $29.2^{\circ} \mathrm{C}$ TE whereas its thermal comfort zone is $28.1-30.3^{\circ} \mathrm{C}$ TE. Those temperature level are still higher than Indonesia National Standard/SNI 6390:2011 $\left(25.5^{\circ} \mathrm{C} \mathrm{TE}\right)$, and also still higher than the result of thermal comfort study of hospital workers in Malaysia (with similar geographical context and average ambient temperature around $23-32^{\circ} \mathrm{C}$ ); $26.4^{\circ} \mathrm{C}$ TE.

2. The energy consumption level of hospital wards in lowland area that dominantly used NV system are: average $61.84 \mathrm{kWh} / \mathrm{m} 2 /$ year; the highest $68.4 \mathrm{kWh} / \mathrm{m} 2 /$ year; the lowest $55.5 \mathrm{kWh} / \mathrm{m} 2 / \mathrm{yr}$.

3. The architecture design aspects of ward that become the dominant factor on thermal performance establishment are the building's orientation toward the sun and the building's layout plan within the site.

\section{ACKNOWLEDGMENTS}

The author would like to thank to all Directors and staffs of five hospitals as mentioned above where the research was taken, who are generous and highly supportive during the moments we did respondents' interview, the collection of climatic parameter data, the collection of building's electricity energy consumption data and the architecture design aspects data. Finally, the author wishes to thank to all respondents who participated in this research.

\section{REFERENCES}

[1] E. R. Ballantyne, A Survey of Thermal Sensation in Port Moresby, Papua New Guinea; Commonwealth Scientific and Industrial Research Organization, Canberra, Australia, 1979.

[2] G.S. Brager, R..J. de Dear, Climate, comfort and natural ventilation: A new adaptive comfort standard for Ashrae standard 55. In Proceedings of Windsor Conference: Moving Thermal Comfort Standards into the 21st Century, Windsor, UK, 5-8 April 2001.

[3] J.F. Busch, Thermal Responses to the Thai Office Environment. ASHRAE Trans, 96, 859-872,1990.

[4] R.J. de Dear, K.G. Leow S.C., Foo, Thermal comfort in the humid tropics: Field experiments in air conditioned and naturally ventilated buildings in Singapore., Int. J. Biometeorol, 34, 259-265, 1991.

[5] R. de Vecchi, C. Candido. R. Lamberts, Thermal history and its influence on occupants' thermal acceptability and cooling preferences in warm humid climates: A new desire for comfort? In Proceedings of the 7th Windsor Conference: The Changing Context of Comfort in an Unpredictable World Cumberland Lodge, Windsor, UK, 12-15 April 2012.

[6] Fanger, Thermal Comfort Analysis and Applications in Environmental Engineering, Robert E Kreiger Publishing Company, Malabar, Florida, 1970.

[7] H. Feriadi, N.H. Wong, Thermal comfort for naturally ventilated houses in Indonesia, Energy Build, 36, 614-626, 2004.

[8] T. H. Karyono, at al., Thermal Comfort Studies in Naturally Ventilated Buildings in Jakarta, Indonesia, Buildings, 5(3), 917-932, 2015.

[9] T. H. Karyono and R. Delyuzir, "Thermal comfort studies of primary school students inTangerang, Indonesia”, Proceedings of 9th Windsor Conference: Making Comfort Relevant Cumberland Lodge, Windsor, UK, 7-10 April 2016. Network for Comfort and Energy Use in Buildings, http://nceub.org.uk

[10] W. Yang, G. Zhang, Thermal comfort in naturally ventilated and air-conditioned buildings in humid subtropical climate zone in China, Int. J. Biometeorol., 52, 385-398, 2008.

[11] T. H. Karyono, Solar Energy and Architecture; A Study Of Solar Passive Design for Hospital Wards in Indonesia, 1989.

[12] F. Idiealistina, Model Termoregulasi Tubuh untuk Penentuan Besaran Kesan Termal Terbaik dalam kaitannya dengan Kinerja Manusia, Doctoral Thesis, Bandung Institute Technology (ITB), Indonesia, 1991.

[13] N. Lechner, Heating, Cooling, Lighting; Design Methods for Architects, John Wiley \& Sons, Inc. 2001.

[14] B. Stein, Building Technology; Mechanical \& Electrical Systems, John Wiley \& Sons, Inc., 1997.

[15] T.H. Karyono, Teori dan Acuan Kenyamanan Termis dalam Arsitektur, PT Catur Libra Optima, Jakarta, 2001.

[16] T.H. Karyono, Predicting Comfort Temperature in Indonesia, an Initial Step to Reduce Cooling Energy Consumption, Buildings, 5, 802-813, 2015.www.mdpi.com/journal/buildings

[17] M.A. Humphrey, Thermal comfort requirements, climate and energy, In Proceedings of 2nd WREC Conference, Reading, UK, 13-18 September 1992.

[18] R.F. Carr, Hospital Planning and Design, Nika Technologies, Inc., 2011.

[19] L. Frank, D. Engelke, Peter O. Schmid, L. Thomas, "Health and Community Design; The Impact of the Built Environment on Physical Activity”, 2003.

[20] R. Guenther \& G. Vittori, Sustainable Healthcare Architecture, John Wiley \& Sons, Inc., 2008

[21] F. Nicol, S. Roaf, M.A. Humphreys, Adaptive Thermal Comfort: Principles and Practice, Routledge: Oxon, UK, 2012.

[22] F. Nicol, Adaptive thermal comfort standards in the hot-humid tropic, Energy and Buildings, 36(7): 628- 637, 2004. 
[23] T.H. Karyono at al., Air conditioning and the neutral temperature of the Indonesian university students, Architectural Science Review Publication. http://www.tandfonline.com/loi/tasr20 Indonesia Published online, 23 Jan 2015.

[24] International Conference on Passive and Low Energy Cooling for the Built Environment, pp. 207-211, 2005.

[25] T.H. Karyono, Arsitektur Tropis; Bentuk, Teknologi, Kenyamanan \& Penggunaan Energi, 2016.T.H. Karyono, G. Bahri, Energy efficient strategies for JSX building in Jakarta, Indonesia.

[26] T.H. Karyono, Green Architecture: Pengantar Pemahaman Arsitektur Hijau di Indonesia, Rajawali Pers, Jakarta, 2010.

[27] T.H. Karyono, Arsitektur dan Kota Tropis Dunia Ketiga; Suatu Bahasan Tentang Indonesia, Rajawali Pers, Jakarta, 2013.

[28] Y.H. Yau and B. T. Chew. Thermal comfort study of hospital workers in Malaysia. Indoor Air, 19 (6): 500-510, 2009.

[29] F. Azizpour, S. Moghimi, C. H. Lim, S. Mat, E. Salleh and K. Sopian, A Thermal Comfort Investigation of a Facility Department of Hospital in Hot-HumidClimate: Correlation between Objective and Subjective Measurements, Indoor and Built Environment, 22(5): 836-845, 2012.

\section{AUTHOR PROFILE}

Yuyus Mulia is a practitioner in architecture design. Interested in building design especially hospital buildings. Architecture scholar education was taken at Parahyangan Catholic University, Indonesia. Architecture post-graduate education at Bandung Institute of Technology, Indonesia. Architecture doctoral education at Parahyangan Catholic University, Indonesia.

Gagoek Hardiman is a professor and practitioner in architecture, currently teaching architecture in postgraduate and doctoral program Diponegoro University, Indonesia. Architecture scholar education was taken at Diponegoro University, Indonesia. Dr. Ing. in architecture was taken at The University of Stuttgart, Germany.

Kamal A. Arif is a lecturer and practitioner in architecture, currently teaching architecture in post-graduate and doctoral program Parahyangan Catholic University. Architecture scholar education was taken at Parahyangan Catholic University, Indonesia. Master of engineering on structural engineering and construction was taken at Asian Institute of Technology, Bangkok, Thailand. Architecture doctoral education was taken at Parahyangan Catholic University, Indonesia. 